\title{
The Role of Allium subhirsutum L. in the Attenuation of Dermal Wounds by Modulating Oxidative Stress and Inflammation in Wistar Albino Rats
}

\author{
Mongi Saoudi ${ }^{1, *,+} \mathbb{D}$, Riadh Badraoui ${ }^{2,3, *,+} \mathbb{D}$, Ahlem Chira ${ }^{1}$, Mohd Saeed ${ }^{2} \mathbb{D}$, Nouha Bouali ${ }^{2}$, Salem Elkahoui $^{2}$, \\ Jahoor M. Alam ${ }^{2} \mathbb{D}$, Choumous Kallel ${ }^{4}$ and Abdelfattah El Feki ${ }^{1}$
}

check for updates

Citation: Saoudi, M.; Badraoui, R.; Chira, A.; Saeed, M.; Bouali, N.; Elkahoui, S.; Alam, J.M.; Kallel, C.; El Feki, A. The Role of Allium subhirsutum L. in the Attenuation of Dermal Wounds by Modulating Oxidative Stress and Inflammation in Wistar Albino Rats. Molecules 2021, 26 , 4875. https://doi.org/10.3390/ molecules26164875

Academic Editors: Stefano Castellani and Massimo Conese

Received: 5 July 2021

Accepted: 9 August 2021

Published: 12 August 2021

Corrected: 22 August 2022

Publisher's Note: MDPI stays neutral with regard to jurisdictional claims in published maps and institutional affiliations.

Copyright: (c) 2021 by the authors. Licensee MDPI, Basel, Switzerland. This article is an open access article distributed under the terms and conditions of the Creative Commons Attribution (CC BY) license (https:/ / creativecommons.org/licenses/by/ $4.0 /)$.
1 Animal Ecophysiology Laboratory, Sciences Faculty of Sfax, University of Sfax, Sfax 3054, Tunisia; chiraahlem@gmail.com (A.C.); abdelfattahelfeki@fss.rnu.tn (A.E.F.)

2 Laboratory of General Biology, Department of Biology, University of Ha'il, Ha'il 81451, Saudi Arabia; mo.saeed@uoh.edu.sa (M.S.); nouha_bmail@yahoo.fr (N.B.); s.elkahoui@uoh.edu.sa (S.E.); j.alam@uoh.edu.sa (J.M.A.)

3 Section of Histology and Cytology, Medicine Faculty of Tunis, University of Tunis El Manar, La Rabta, Tunis 1007, Tunisia

4 Hematology Laboratory, Hospital Habib Bourguiba, Sfax 3029, Tunisia; kallelC@yahoo.fr

* Correspondence: mongifss@yahoo.fr (M.S.); riadh.badraoui@fmt.utm.tn (R.B.); Tel.: +216-99740205 (M.S.)

+ These authors contributed equally to this work.

\begin{abstract}
In our study, Allium subhirsutum L. (AS) was investigated to assess its phenolic profile and bioactive molecules including flavonoids and organosulfur compounds. The antioxidant potential of AS and wound healing activity were addressed using skin wound healing and oxidative stress and inflammation marker estimation in rat models. Phytochemical and antiradical activities of AS extract (ASE) and oil (ASO) were studied. The rats were randomly assigned to four groups: group I served as a control and was treated with simple ointment base, group II was treated with ASE ointment, group III was treated with ASO ointment and group IV (reference group; Ref) was treated with a reference drug "Cytolcentella ${ }^{\circledR}$ cream". Phytochemical screening showed that total phenols $(215 \pm 3.5 \mathrm{mg} \mathrm{GAE} / \mathrm{g})$ and flavonoids $(172.4 \pm 3.1 \mathrm{mg}$ QE/g) were higher in the ASO than the ASE group. The results of the antioxidant properties showed that ASO exhibited the highest DPPH free radical scavenging potential $(\mathrm{IC} 50=0.136 \pm 0.07 \mathrm{mg} / \mathrm{mL})$, FRAP test $(\mathrm{IC} 50=0.013 \pm 0.006 \mathrm{mg} / \mathrm{mL})$, ABTS test (IC50 $=0.52 \pm 0.03 \mathrm{mg} / \mathrm{mL})$ and total antioxidant capacity $(\mathrm{IC} 50=0.34 \pm 0.06 \mathrm{mg} / \mathrm{mL}$ ). In the wound healing study, topical application of ASO performed the fastest wound-repairing process estimated by a chromatic study, percentage wound closure, fibrinogen level and oxidative damage status, as compared to ASE, the Cytolcentella reference drug and the untreated rats. The use of AS extract and oil were also associated with the attenuation of oxidative stress damage in the wound-healing treated rats. Overall, the results provided that AS, particularly ASO, has a potential medicinal value to act as effective skin wound healing agent.
\end{abstract}

Keywords: Allium subhirsutum L.; wound-healing activity; antioxidant potential; inflammatory marker; oxidative stress

\section{Introduction}

Wound healing is a complicated and dynamic physiological process in response to tissue impairment [1]. It is a fundamental connective tissue response [2] to tissue impairment through three phases, including hemostasis and inflammation, proliferation and remodeling [3]. Cutaneous wound healing involves several mediators, such as fibroblasts, endothelial cells, blood cells, interactions with extracellular phases and granulation tissue remodeling phases [4,5]. Furthermore, reactive oxygen species (ROS) are produced in response to cutaneous injury, and act as cellular messengers to stimulate several physiological processes, such as cytokine action, cell motility and angiogenesis [4]. However, 
cutaneous injury affects the healing process by the overproduction of ROS and the perturbation of various enzymatic and non-enzymatic antioxidant defenses [6], particularly during the inflammatory phase [7]. Long-term instability and high concentration of ROS may cause cellular injury by damaging both proteins and membrane lipids, the perturbation of antioxidant enzymes and the breakdown of the nucleic acids, particularly DNA $[8,9]$. Higher concentrations of intracellular ROS might eventually lead to angiogenesis pathological damage, promoting inflammation $[10,11]$, which makes blood flow and nutritional requirements unable to meet the needs of wound healing [12].

Many antioxidants in medicinal plant extracts are used to eliminate the negative effects of ROS-associated pathologies and/or injuries including wound healing [11,13,14]. Over the years, medicinal plants have been used to develop a variety of formulations that combat injuries such as wounds, burns and cuts [15]. Several ethno-medicinal plants have been used for medicinal applications thanks to their wide biological activities and medicinal applications due to counteracting oxidative stress potential, lesser costs and high safety margins [16-18]. Plant extracts are known to exhibit many pharmacological properties (anti-hyperlipidemic, anti-proliferative, and immunomodulatory, etc.) through the multitude amounts of natural polyphenolic antioxidants [17-19].

Garlic species are used as dietary supplements and an important ingredient for cooking in many parts of the world and their application in medicinal remedy has also increased its popularity $[11,17,20]$. Garlic species are known to have diverse biological activities, particularly due to their antioxidant properties. Allium subhirsutum L. is an aromatic plant known since antiquity. It was investigated in terms of its potential antioxidant components such as flavonoids and polyphenols $[10,11,21]$. Previous studies reported that it is a potential source of anticancer and antioxidant molecules [16]. It is a very rich source of valuable compounds, such as polyphenols, vitamins, flavonoids, carotenoids and carbohydrates [17]. Experimental studies showed that garlic phenolic compounds and flavonoids may promote epithelialization and stimulate new tissue growth, fluid handling and moist wound healing [22]. As regards to its pharmacological properties, garlic has been revealed to display antidiabetic, hepatoprotective, antimicrobial, renoprotective, immunomodulatory and anti-inflammatory properties [23].

Furthermore, garlic is also rich in different bioactive compounds like allicin, glutathione diallyl sulfides [24] and important minerals (selenium, manganese and zinc) which encourage its consumption. Pre-treatment with garlic significantly reduced levels of ROS, lipid peroxidation and DNA damage, and thus enhanced the antioxidant system [11,25]. Recent studies [26] revealed that the application of bioactive molecules with antioxidant activities improved wound healing and protected against oxidative damage. Wound care medicinal plants in the form of ointment could ameliorate wound healing and tissue repair with minimal side effects [27]. Previous studies reported that infections in the locations of injured skin are the main reasons for mortality in hospitalized patients with extensive burns [28]. For that reason, the application of plant medicinal preparations as local ointment with considerable antimicrobial effects can significantly reduce the risk of burn wound infections and alleviate the period of treatment [29]. Garlic has been reported to accelerate wound contraction rate, validated by a significant improvement and an increase in the rate of wound closure and a reduction in the time taken by the granulation tissue and inflammatory marker levels to fall [30].

With these considerations, the current study aimed to evaluate wound healing activity of AS extract and oil, using a skin wound healing rat model via the estimation of oxidative stress and anti-inflammatory parameters. This research on the antioxidants and in vivo biological activities of AS can improve its commercial value and help to develop new nutritional and health products. 


\section{Results \& Discussion}

\subsection{Phytochemical Analysis}

In the current study, the phytochemical analysis of Allium subhirsutum L. extract and oil showed their richness in phenolic and flavonoid compounds. Furthermore, higher contents of polyphenols and flavonoids confirmed the presence of these biomolecules in ASO.

Total polyphenols, flavonoids and tannins of Allium subhirsutum L. extract and oil were calculated according to the calibration curves and the phytochemical amounts are shown in Table 1. Phytochemical screening showed that total polyphenol (215 $\pm 3.5 \mathrm{mg}$ GAE/g) and flavonoid (172.4 $\pm 3.1 \mathrm{mg}$ QE/g) amounts are higher in the ASO than the ASE. However, the total tannin level was higher $(387.5 \pm 17.2 \mathrm{mg}$ QE/g) in the ASE than ASO, in which it was not detected. Total polyphenols, flavonoids and tannins of Allium subhirsutum L. extract and oil were calculated according to the calibration curves (see Supplementary Figure S1). The richness in phenolic and flavonoid compounds have been highlighted in Allium subhirsutum by previous studies, including those realized by our team [11,17]. Nevertheless, the variations in such compounds might be related to the region of the plant collection.

Table 1. Amounts of total phenolic components, flavonoids, tannins and IC50 for the DPPH scavenging activity, ferric reducing antioxidant power (FRAP), ABTS antioxidant activity and total antioxidant capacities (TAC) of Allium subhirsutum L. extract and oil. Ascorbic acid was used as standard.

\begin{tabular}{|c|c|c|c|c|c|c|c|}
\hline $\begin{array}{l}\text { Samples } \\
\text { and } \\
\text { Parameters }\end{array}$ & $\begin{array}{c}\text { Total } \\
\text { Polyphenols } \\
\text { (mg GAE/g) }^{\mathbf{b}}\end{array}$ & $\begin{array}{l}\text { Flavonoids }^{a} \\
\text { (mg EQ/g) }^{c}\end{array}$ & $\begin{array}{l}\text { Tannins a } \\
\text { (mg EQ/g) }\end{array}$ & $\begin{array}{c}\text { DPPH }{ }^{\mathrm{a}} \\
\text { IC50 (mg/mL) }\end{array}$ & $\begin{array}{c}\text { FRAP a }^{a} \\
\text { IC50 (mg/mL) }\end{array}$ & $\begin{array}{c}\text { ABTS }^{\text {a }} \\
\text { IC50 (mg/mL) }\end{array}$ & $\begin{array}{c}\text { Total } \\
\text { Antioxidant } \\
\text { Capacity }^{\mathrm{a}} \\
\text { (mg VitC/g) }^{\mathrm{d}}\end{array}$ \\
\hline $\begin{array}{c}\text { A. subhirsutum } \mathrm{L} \text {. } \\
\text { extract }\end{array}$ & $63.8 \pm 2.36$ & $41.7 \pm 3.4$ & $387.5 \pm 17.2$ & $0.20 \pm 0.004$ & $0.05 \pm 0.004$ & $0.54 \pm 0.04$ & $0.45 \pm 0.09$ \\
\hline $\begin{array}{l}\text { A. subhirsutum } \mathrm{L} \text {. } \\
\text { oil }\end{array}$ & $215 \pm 3.5$ & $172.4 \pm 3.1$ & ND & $0.136 \pm 0.07$ & $0.013 \pm 0.006$ & $0.52 \pm 0.03$ & $0.34 \pm 0.06$ \\
\hline Ascorbic acid & - & - & - & $0.118 \pm 0.006$ & $0.08 \pm 0.004$ & $0.09 \pm 0.09$ & $0.124 \pm 0.002$ \\
\hline
\end{tabular}

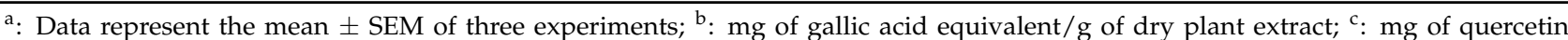
equivalent/g of dry plant extract; ${ }^{\mathrm{d}}$ : mg Vitamin C equivalent/g of dry plant extract; ND: not detected; - : not tested.

\subsection{Antioxidant Potential Analysis}

The antioxidant properties of the extract and oil of Allium subhirsutum L. were assessed via several approaches: scavenging activity on DPPH free radicals, reducing power, total antioxidant activity assay by ABTS and total antioxidant capacity. The results are summarized in Table 1. The antioxidant activities of the studied Allium subhirsutum L. extract and oil were compared with vitamin C as a standard antioxidant. The Allium subhirsutum L. oil exhibited the highest DPPH free radical scavenging potential $($ IC50 $=0.136 \pm 0.07 \mathrm{mg} / \mathrm{mL}$ ), FRAP test $(\mathrm{IC} 50=0.013 \pm 0.006 \mathrm{mg} / \mathrm{mL})$, ABTS test $(\mathrm{IC} 50=0.52 \pm 0.03 \mathrm{mg} / \mathrm{mL})$ and total antioxidant capacity (IC50 $=0.34 \pm 0.06 \mathrm{mg} / \mathrm{mL}$ ), as compared to Allium subhirsutum L. extract. The results revealed an important difference of the DPPH, FRAP, ABTS and total antioxidant capacity tests between the standard vitamin $C$ and the different extracts. Furthermore, the Allium subhirsutum L. extract and oil showed potential antioxidant activities as compared to vitamin C; thus, it is able to scavenge superoxide and peroxyl radicals.

Antioxidant activities as estimated by DPPH free radicals, reducing power, total antioxidant activity assay and total antioxidant capacities in ASO explain the ROS scavenging capacity, but it was less than the standard vitamin C. The antioxidant status of ASO is related to the major active components such as organosulfur molecules and their derivatives. Many garlic supplements such as garlic oil macerate, garlic oil, dehydrated garlic powder and aged garlic extract are currently commercially available [31]. 


\subsection{Wound Closure}

\subsubsection{Chromatic Study}

Considering the medicinal application of Allium subhirsutum L. and the in vitro antioxidant activity, the plant was further evaluated for skin lesion potential, particularly burns and wounds. Several garlic species have been evaluated in different animal models and were reported to display cutaneous wound healing [32].

The wound healing activity was checked by a chromatic assessment based on the progressive variations of both wound color and surface during the experimental study. The different phases of cicatrization of all studied groups are shown in Figure 1.

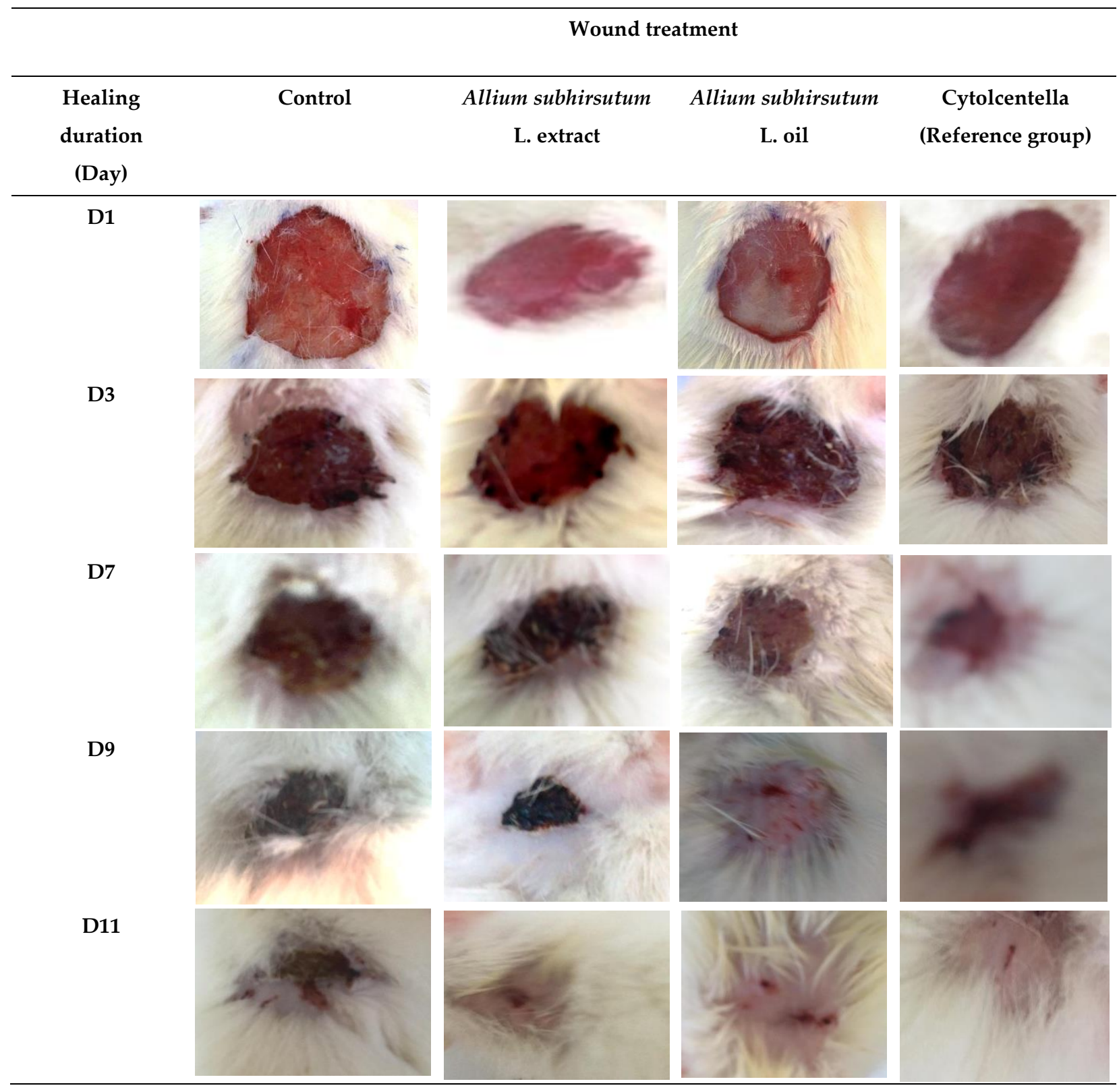

Figure 1. Photographic illustrations of wound healing process in the different experimental groups on $1,3,7,9$ and 11 days post-wounding.

The selected days $(1,3,7,9$ and 11) correspond to the wound induction day, the epithelialization progress and the inflammatory evolution. The wounds' photographic representations denoted a similar surface and colored wound areas in the first three days for the different studied groups of rats. The photographs of the wound revealed a bright 
red color during the first day that turned dark red on the third day, which proves blood clot formation. By the seventh day of wound healing, a large inflammatory bulb in the control group was noted, while the wound surfaces of Allium subhirsutum L. extract and oil-treated and Cytolcentella-treated rats were smaller. From the ninth day, in the rats treated with ASO and Cytolcentella (Ref group), the crusts began to fall off revealing a red granulated tissue, which characterized completed epithelialization around the 11th day. The process was exhibited at the eleventh day to the complete wound closure in the ASO and Cytolcentella reference drug groups. However, the Allium subhirsutum L. extract and control group wounds showed residual scabs and healed slower. The closure was uncompleted in the control and Allium subhirsutum L. extract-treated groups.

The wound photographic representations of the treated groups ASO and Cytolcentella reference drug showed better and more advanced epithelial regeneration when compared to the control group (group I). This faster wound closure of Allium subhirsutum L. oil, as compared to the ointment by Cytolcentella reference drug, could presumably be due to the richness of Allium subhirsutum L., particularly polyphenols and flavonoids, and with several other bioactive compounds (sulfur-rich compounds), as demonstrated by Badraoui et al. [17] Previous findings $[11,17,33]$ revealed that polyphenols play a key role in the proliferation of epithelial cells and the regulation of angiogenesis.

\subsubsection{Effect of Allium Subhirsutum L. Extract and Oil on Percentage Wound Closure}

The changes in the percentage of wound closure in control, Allium subhirsutum L. extract and oil, and the reference drug "Cytolcentella" groups were followed on some selected days (Figure 2).



Figure 2. Effects of Allium subhirsutum L. extract (ASE), Allium subhirsutum L. oil and the reference drug "Cytolcentella ${ }^{\circledR}$ " on the percentage of wound closure in control and treated rats. Data represent the mean \pm SEM for six rats. Statistically significant variations are compared as follows: ASE, ASO and Ref treated groups compared to control group. * and ** indicate significant differences when $p<0.05$ and $p<0.01$, respectively.

The Allium subhirsutum L. extract and oil group displayed a marked wound-healing potential as compared to the untreated group and the Cytolcentella reference drug group. However, the Allium subhirsutum L. extract showed a lower wound-healing process as compared to the Allium subhirsutum L. oil and Cytolcentella reference drug groups. On days 9 and 10, a rapid reduction in wound area of the Allium subhirsutum L. oil group was observed $(p<0.01)$, which was comparable to the Cytolcentella reference drug group.

The reference group showed the strongest wound contraction rate throughout healing days and complete healing of the wound $(100 \%)$ was observed on the 11th day, while the Allium subhirsutum L. extract and oil group showed $81.25 \%$ and $87 \%$ healing on same day, 
respectively. It was also noticed that no comparable wound area evolution was observed between the ASO, ASE and Cytolcentella groups on the first 3 days.

Additionally, the morphometric assessment exhibited an increased wound contraction rate of the wounds following ASO and the Cytolcentella reference drug treatment as compared to the untreated group. Previous research using an aqueous extract of garlic (Allium sativum) showed a higher percentage of burn wound contraction in rats treated with $0.4 \%$ garlic topical cream (88.1\%) than those treated with cream base $(70.3 \%)$ [28]. This rapid wound closure may be attributed to an increase in fibroblast activity, which is crucial for normal wound contraction.

\subsubsection{Effect on Inflammatory Marker}

The inflammatory marker of different groups was analyzed to determine the level of fibrinogen (Figure 3), which is known as an inflammatory protein. An increased level of this protein revealed a condition of inflammation. Fibrinogen content was found to be significantly alleviated in Allium subhirsutum L. oil $(p<0.001)$ and the Cytolcentella reference drug $(p<0.01)$ groups, followed by Allium subhirsutum L. extract $(p<0.01)$ as compared to control group.

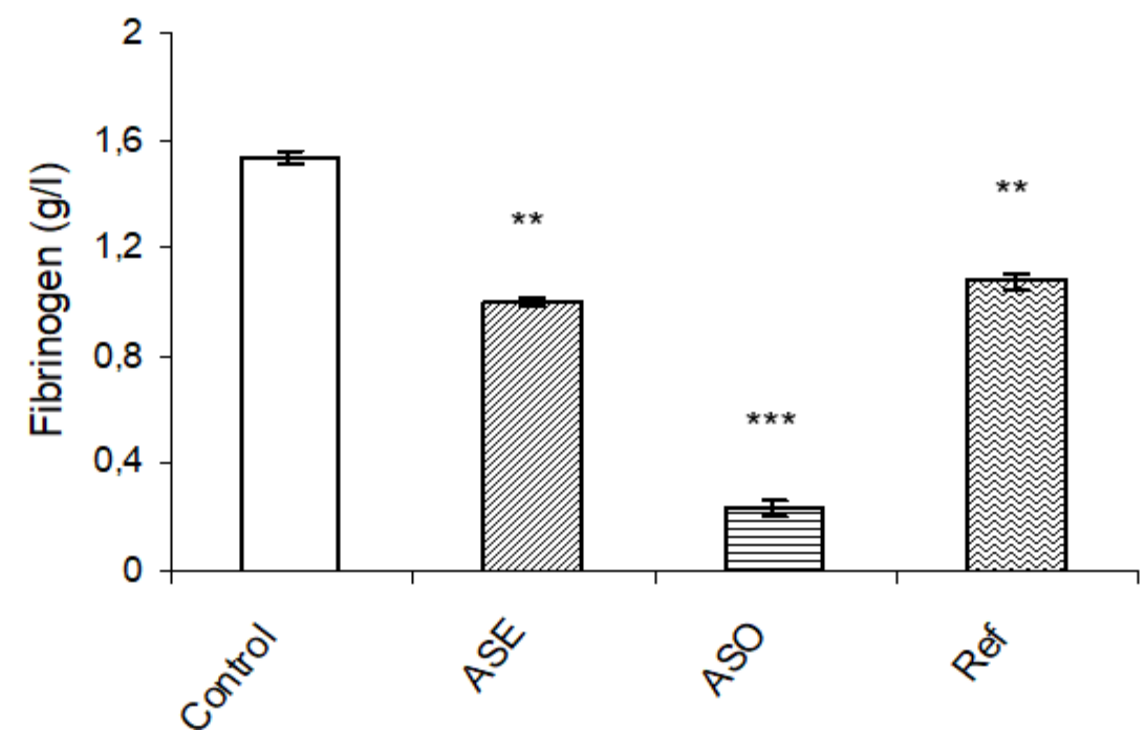

Figure 3. Effects of Allium subhirsutum L. extract (ASE), Allium subhirsutum L. oil and the reference drug "Cytolcentella ${ }^{\circledR}$ " on fibrinogen level. Data represent the mean \pm SEM for six rats. Statistically significant variations are compared as follows: ASE, ASO and Ref treated groups compared to control group: ${ }^{* *}$ and ${ }^{* * *}$ indicate significant differences when $p<0.01$ and $p<0.001$, respectively.

The results confirmed reduced levels of the inflammatory marker (fibrinogen content) on topical treatments with ASO and ASE as compared to the control group and the reference drug Cytolcentella group. The present study corroborates previous findings [11,34], which notified that phenolic compounds have the potency to attenuate the inflammatory markers as well as pro-inflammatory cytokines, which accelerate the mechanism of collagenation and maturation of granulation tissue.

\subsection{Oxidative Stress Profile}

Recent findings have shown that oxidative stress can cause cell damage [9,35-37] and delay wound healing [38]. The formation of free radicals and a low capacity to scavenge ROS are causative of skin lesions. After an overproduction of ROS, an increase in oxidative stress markers, as estimated by lipid peroxidation and protein oxidation molecules resulted in the healing process delay. The attenuation of excessive ROS generation significantly accelerates the healing process. The cells respond by developing a defense mechanism 
that consists of producing antioxidant enzymes, including superoxide dismutase (SOD), catalase (CAT) and glutathione peroxidase (GPx).

\subsubsection{Oxidative Stress Markers of Granulation Tissue}

The levels of wound tissues TBARS, CD, AOPP and CP are shown in Table 2. Results indicated that untreated control rats possessed the highest oxidative stress markers, proving the presence of an oxidative stress state in these rats. However, the application of either Allium subhirsutum L. extract and oil or the reference drug Cytolcentella significantly decreased the levels of TBARS, CD, AOPP and CP in the wound tissues as compared to control.

Table 2. Effects of Allium subhirsutum L. extract (ASE), Allium subhirsutum L. oil and the reference drug "Cytolcentella ${ }^{\circledR}$ " on oxidative stress markers of granulation tissue by estimation of TBARS, CD, AOPPA and CP levels.

\begin{tabular}{ccccc}
\hline $\begin{array}{c}\text { Treatment } \\
\text { \& Parameters }\end{array}$ & $\begin{array}{c}\text { TBARS } \\
\text { (nmol MDA/mg } \\
\text { Protein) }\end{array}$ & $\begin{array}{c}\text { CD } \\
\text { ( } \begin{array}{c}\text { Pmol/mg } \\
\text { Protein) }\end{array}\end{array}$ & $\begin{array}{c}\text { AOPP } \\
(\mu \mathrm{mol} / \mathbf{m g} \\
\text { Protein) }\end{array}$ & $\begin{array}{c}\text { CP } \\
\text { ( } \mu \mathrm{mol} / \mathbf{m g} \\
\text { Protein) }\end{array}$ \\
\hline Control & $1.38 \pm 0.138$ & $0.69 \pm 0.04$ & $0.25 \pm 0.01$ & $61.37 \pm 0.37$ \\
ASE & $1.08 \pm 0.09^{*}$ & $0.58 \pm 0.13^{*}$ & $0.23 \pm 0.003$ & $50.73 \pm 1.28^{* *}$ \\
ASO & $0.91 \pm 0.37^{*}$ & $0.48 \pm 0.11^{* *}$ & $0.21 \pm 0.003^{*}$ & $47.63 \pm 1.09^{* *}$ \\
Ref & $0.82 \pm 0.014^{* *}$ & $0.45 \pm 0.01^{* * *}$ & $0.20 \pm 0.006^{* *}$ & $41.80 \pm 1.14^{* * *}$ \\
\hline
\end{tabular}

The oxidative stress marker parameters: TBARS: Thiobarbituric acid-reactive substances; CD: conjugated dienes AOPP: advanced oxidation of protein products; CP: carbonyl protein. Data represent the mean \pm SEM for six rats. Statistically significant variations are compared as follows: ASE, ASO and Ref treated groups compared to control group. ${ }^{*}{ }^{* *}$ and ${ }^{* *}$ indicate significant differences when $p<0.05, p<0.01$ and $p<0.001$, respectively.

In our experiment, the treatment with ASO and ASE significantly decreased wound tissue levels TBARS, CD, AOPP and CP as compared to control rats. These results are in accordance with previous results $[11-14,17,39]$, which reported that plants, specifically hairy garlic, possessed high antioxidant and free radical-scavenging effects. It may be attributed to the presence of active biomolecules in Allium subhirsutum L. oil which ultimately cause an antioxidant activity and wound repairing. The availability of bioactive molecules such polyphenols and flavonoids, and the ROS-scavenging ability of Allium subhirsutum L. helped in lowering the ROS levels, thus accelerating the wound closure.

\subsubsection{Enzymatic Antioxidant Profile of Granulation Tissue}

Several studies have shown that enzymatic antioxidant profiles such as SOD, CAT and GPx scavenge free radicals and prevent oxidative damage.

Antioxidant enzyme profiles (SOD, CAT and GPx) of control and treated rats are summarized in Table 3. The tissue antioxidant enzymatic activities of the control group were the lowest. The pre-treatment with Allium subhirsutum L. and the reference drug Cytolcentella showed a significant increase in the enzymatic activities as compared to the control group. 
Table 3. Effects of Allium subhirsutum L. extract (ASE), Allium subhirsutum L. oil and the reference drug "Cytolcentella ${ }^{\circledR}$ " on enzymatic antioxidant profile of granulation tissue by estimation of SOD, CAT and GPx activities.

\begin{tabular}{cccc}
\hline $\begin{array}{c}\text { Treatment \& } \\
\text { Parameters }\end{array}$ & $\begin{array}{c}\text { SOD } \\
\text { (Units/mg } \\
\text { Protein) }\end{array}$ & $\begin{array}{c}\text { CAT } \\
\left(\mu \text { mol H}_{\mathbf{2}} \mathbf{O}_{2} / \mathbf{m g}\right. \\
\text { Protein) }\end{array}$ & $\begin{array}{c}\text { GPx } \\
(\mu \mathrm{mol} \mathrm{GSH} / \mathbf{m i n} / \mathbf{m g} \\
\text { Protein) }\end{array}$ \\
\hline Control & $18.47 \pm 0.29$ & $50.50 \pm 1.18$ & $0.009 \pm 0.0006$ \\
ASE & $21.24 \pm 2.71^{*}$ & $53.07 \pm 0.54^{*}$ & $0.014 \pm 0.0081^{* *}$ \\
ASO & $22.30 \pm 3.81^{*}$ & $57.50 \pm 1.85^{* *}$ & $0.028 \pm 0.012^{* * *}$ \\
Ref & $23.61 \pm 0.99^{* *}$ & $69.61 \pm 1.40^{* * *}$ & $0.037 \pm 0.0003^{* * *}$ \\
\hline
\end{tabular}

The enzymatic antioxidant profile: SOD: superoxide dismutase; CAT: catalase; GPx: glutathione peroxidase. Data represent the mean \pm SEM for six rats in each group. Statistically significant variations are compared as follows: ASE, ASO and Ref treated groups compared to control group: ${ }^{*}, * *$ and ${ }^{* * *}$ indicate significant differences when $p<0.05, p<0.01$ and $p<0.001$, respectively.

In the current study, we observed an increase in SOD, CAT and GPx activities in the wound area in rats treated with ASO, ASE and the reference drug as compared to control rats. These results revealed that topical application of Allium subhirsutum L. oil and extract protected against cellular damage by the stimulation and/or the expression of the antioxidant enzymes. Our findings are in accordance with the data authored by Khan et al. [23], in which they reported that Allium sativum oil protected against oxidative damage in fish exposed to silver nanoparticles (Ag-NPs), and with Zammel et al. [11], where Allium subhirsutum was found to protect against carrageenan-induced paw edema, inflammation and oxidative damage in rats.

2.4.3. Correlation Matrix between Phytochemicals of Allium subhirsutum L., Oxidative Stress, Fibrinogen and Wound Reduction

Table 4 presented the correlation matrix between the antioxidant equivalent markers (polyphenols, flavonoids, tannins), the oxidative/antioxidative status, the fibrinogen level and the percentage of wound reduction (on the 11th day of treatment). As shown in Table 4, this correlation matrix revealed that AOPP oxidative stress marker, SOD and CAT enzymatic antioxidant activities were positively correlated with the antioxidant equivalent marker in Allium subhirsutum extract and oil (polyphenols, flavonoids and tannins), indicating its involvement in the attenuation of oxidative stress damage, as previously confirmed by several other reports [11,40].

Allium subhirsutum oil protected against oxidative damage as demonstrated by the SOD and GPx activities which were positively correlated with the polyphenols and flavonoids contents of ASO. A similar positive correlation was previously observed in Lonicera caerulea L. polyphenols that alleviated oxidative stress-induced intestinal environment imbalance and lipopolysaccharide-induced liver injury in high-fat diet-fed rats [41].

Table 4. Correlation matrix between phytochemicals, oxidative stress markers, fibrinogen and wound reduction.

\begin{tabular}{|c|c|c|c|c|c|c|c|c|c|c|c|c|c|c|c|c|c|c|c|}
\hline & \multirow[b]{2}{*}{$\begin{array}{l}\text { Parameters } \\
\text { \& Groups }\end{array}$} & \multicolumn{2}{|c|}{ TBARS } & \multicolumn{2}{|c|}{ CD } & \multicolumn{2}{|c|}{ АOPP } & \multicolumn{2}{|c|}{$\mathrm{CP}$} & \multicolumn{2}{|c|}{ SOD } & \multicolumn{2}{|c|}{ CAT } & \multicolumn{2}{|c|}{ GPx } & \multicolumn{2}{|c|}{ Fibrinogen } & \multicolumn{2}{|c|}{$\begin{array}{c}\text { Wound } \\
\text { Reduction }\end{array}$} \\
\hline & & ASE & ASO & ASE & ASO & ASE & ASO & ASE & ASE & ASO & ASO & ASE & ASO & ASE & ASO & ASE & ASO & ASE & ASO \\
\hline \multirow{3}{*}{$\begin{array}{l}\text { Extract } \\
\text { of AS }\end{array}$} & Polyphenols & -0.940 & -0.140 & 0.824 & 0.037 & 0.544 & -0.323 & -0.762 & -0.762 & 0.144 & $0.999 *$ & -0.762 & 0.144 & -0.961 & 0.999 * & 0.16 & -0.55 & -0.28 & -0.87 \\
\hline & Flavonoids & 0.630 & 0.981 & -0.806 & 0.932 & 0.615 & $1.000 *$ & -0.362 & -0.362 & -0.982 & -0.296 & -0.362 & -0.982 & 0.053 & -0.296 & -0.98 & -0.60 & -0.82 & 0.76 \\
\hline & Tannins & -0.174 & 0.787 & -0.079 & 0.884 & 0.999 * & 0.658 & -0.942 & -0.942 & -0.785 & 0.528 & -0.942 & -0.785 & -0.720 & 0.528 & -0.78 & $-0.99 *$ & -0.97 & 0.00 \\
\hline \multirow{2}{*}{$\begin{array}{l}\text { Oil of } \\
\text { AS }\end{array}$} & Polyphenols & -0.859 & 0.049 & 0.702 & 0.225 & 0.693 & -0.138 & -0.871 & -0.871 & -0.045 & 0.988 & -0.871 & -0.045 & -0.996 & 0.988 & -0.03 & -0.70 & -0.45 & -0.76 \\
\hline & Flavonoids & -0.940 & -0.140 & 0.824 & 0.037 & 0.544 & -0.323 & -0.762 & -0.762 & 0.144 & $0.999 *$ & -0.762 & 0.144 & -0.961 & $0.999 *$ & 0.16 & -0.55 & -0.28 & -0.87 \\
\hline
\end{tabular}

Data represent the values obtained by Pearson correlation analysis. * indicate significant differences when $p<0.05$.

\section{Materials and Methods}

\subsection{Plant Material and Extraction}

Fresh plant Allium subhirsutum L. cloves was procured from a local market in the Sfax region, Tunisia in October 2020. The plant specimen was washed under running water 
and skins of the samples were removed. For the extract preparation, Allium subhirsutum L. cloves were extracted and stirred with methanol at $30^{\circ} \mathrm{C}$ for one night. Then, a whatmann filter paper was used to remove the particles. The residue was once more extracted, filtered, concentrated and stored until further use. The oil extraction was determined using the application of pressure as described by the method of Arisanu and Rus [42]. By this method, oil is enhanced by increased mechanical pressure on the oil-bearing material.

\subsection{Phytochemical Analysis}

\subsubsection{Total Phenolic Content}

The total phenolic content of the Allium subhirsutum L. extract and oil was measured using a modified colorimetric Folin-Ciocalteu method [43]. The total phenolic content was expressed as mg of gallic acid equivalents (GAE) per gram of dry weight.

\subsubsection{Total Flavonoid Content}

The total flavonoid content was determined by a colorimetric assay using the aluminum trichloride method according to Chang et al. [44]. Flavonoid content was expressed as $\mathrm{mg}$ of quercetin equivalent $(\mathrm{QE}) /$ gram of extract.

\subsubsection{Total Tannins Content}

The total tannins content of Allium subhirsutum L. extract and oil were determined as described by Broadhurst et al. [45] $50 \mu \mathrm{L}$ of the extract was mixed with vanillin/methanol ( $3 \mathrm{~mL}, 4 \%$ ). After stirring, $1.5 \mathrm{~mL}$ concentrated $\mathrm{HCl}$ was added. After $15 \mathrm{~min}$, the absorbance was measured at $500 \mathrm{~nm}$ and the total tannins content was expressed as $\mathrm{mg}$ quercetin equivalent $(\mathrm{QE})$ /gram of extract.

\subsection{Antioxidant Potential Analysis}

\subsubsection{DPPH Free Radical Scavenging Assay}

The DPPH• (2,2-diphenyl-1-picrylhydrazyl) free radical scavenging activities of Allium subhirsutum L. extract and oil were determined using the stable radical 1.1-diphenyl-2picrylhydrazyl (DPPH), as previously reported by Kirby and Schmidt [46]. A total of $1 \mathrm{~mL}$ of different extract concentrations $\left(0.06-1.0 \mathrm{mg} \times \mathrm{mL}^{-1}\right)$ in methanol was mixed with $1 \mathrm{~mL}$ of DPPH radical solution in methanol $4 \%(w / v)$.

The absorbance of the samples and control solutions were measured at $517 \mathrm{~nm}$ against a blank. The antiradical activity was expressed as IC50 $(\mu \mathrm{g} / \mathrm{mL})$. The inhibition was calculated as follows:

$$
\text { Free radical DPPH inhibition }(\%)=100 \times\left(\mathrm{A}_{\text {control }}-\mathrm{A}_{\text {sample }}\right) / \mathrm{A}_{\text {control }}
$$

where $A_{\text {control }}$ is the absorbance of the control reaction (without the test compound) and $\mathrm{A}_{\text {sample }}$ is the absorbance of the test compound. Ascorbic acid was used as a control.

\subsubsection{Ferric Reducing Antioxidant Power}

The reducing power was assessed using the method described by Oyaizu [47]. Allium subhirsutum L. extract and oil (0.06-1.0 $\left.\mathrm{mg} \times \mathrm{mL}^{-1}\right)$ was mixed with $1 \mathrm{~mL}$ of sodium phosphate buffer $(200 \mathrm{mM}, \mathrm{pH} 6.6)$ and $1 \mathrm{~mL}$ of potassium ferricyanide $\left(1 \%, \mathrm{~K}_{3} \mathrm{Fe}(\mathrm{CN})_{6}\right)$. After incubation at $50{ }^{\circ} \mathrm{C}$ for $20 \mathrm{~min}, 1 \mathrm{~mL}$ of trichloroacetic acid $(10 \%)$ was added. The mixture was then centrifuged for $10 \mathrm{~min}$ at $650 \times \mathrm{g}$. An amount of $1.5 \mathrm{~mL}$ of the supernatant was mixed with $0.1 \mathrm{~mL}$ of ferric chloride $\left(0.1 \%, \mathrm{FeCl}_{3}\right)$ and $1.5 \mathrm{~mL}$ of deionized water. The absorbance was read at $700 \mathrm{~nm}$ and compared to a blank. The IC50 value $\left(\mathrm{mg} \times \mathrm{mL}^{-1}\right)$ was determined and compared to the ascorbic acid activity, which was used as standard. 


\subsubsection{Total Antioxidant Activity Assay by Radical Cation (ABTS+)}

The Trolox equivalent antioxidant capacity (TEAC) determines the reduction in $2,2^{\prime}$ azino-bis(3-ethylbenzothiazoline-6-sulphonic acid, as previously reported by Re et al. [48] The antioxidant activity was expressed as $\mathrm{mg}$ TE/g extract and the IC50 was determined.

\subsubsection{Total Antioxidant Capacities (TAC)}

TAC of the plant substances (extract and oil) were assessed by the phosphomolybdenum method as described by Prieto et al. [49] Briefly, $0.1 \mathrm{~mL}$ of methanolic sample solution was mixed with $1 \mathrm{~mL}$ of the reagent solution $(0.6 \mathrm{M}, 28 \mathrm{mM}$ and $4 \mathrm{mM}$ of sulfuric acid, sodium phosphate and ammonium molybdate, respectively) and incubated in a boiling water bath for $90 \mathrm{~min}$ at $95^{\circ} \mathrm{C}$. After cooling at room temperature, the absorbance was determined at $695 \mathrm{~nm}$ and compared to a bank.

\subsection{Wound Healing Assay}

Due to its anti-inflammatory and antioxidant potentials, Allium subhirsutum L. extract and oil were tested for their wound healing in rats.

\subsubsection{Animals}

A total of 24 male albino Wistar rats weighing between 230-270 g were used for this study. The rats were purchased from the Faculty of Sciences of Gabes, Tunisia. The rats were allowed to acclimatize to the housing conditions $\left(22 \pm 3{ }^{\circ} \mathrm{C}, 12 \mathrm{~h} \mathrm{light} /\right.$ dark cycles and about $42 \%$ humidity). The rats were given a standard diet (SICO, Sfax, Tunisia) and ad libitum. All experiments involving animals were conducted according to the Ethical Committee Guidelines for the care and use of laboratory animals of our institution (University of Sfax, Tunisia) and approved by the local committee.

\subsubsection{Wound Treatment}

After anesthesia (intraperitoneal injection of chloral hydrate), an impression by a round seal of $1 \mathrm{~cm}$ diameter was made on the dorsal thoracic regions of the rats. The skin of the impressed area (sterilized and shaved before circular wound creation) was superficially excised to the full thickness to create the wound area [50].

Wounds rats were randomly divided into 4 groups of 6 rats each. Group I was treated with sterile saline and designated as negative control. Group II was treated with Allium subhirsutum L. extract (ASE), group III was treated with Allium subhirsutum L. oil (ASO), and group IV (reference group) was treated with a reference drug "Cytolcentella ${ }^{\circledR}$ " (Ref).

After cleaning the wounds with sterile saline, all treatments using extract and oil of Allium subhirsutum L. and the reference drug "Cytolcentella ${ }^{\circledR}$ " were topically applied every two days until sacrifice.

\subsubsection{Percentage of Wound Closure Rate}

The wound perimeters were traced using transparent paper and the percentage of the healed area was recorded. The percentage of wound closure was calculated using the following formula [51]:

Wound closure $(\%)=($ Area of wound on day $0-$ Area of wound on nth day $) /($ area of wound on day 0$) \times 100$ where $\mathrm{n}$ represents the number of days, i.e., $3 \mathrm{rd}$, 5 th, 7 th, 9 th and 11 th.

The required number of days for complete wound contraction was registered together with the re-epithelialization progress and the infection evolution were evaluated using macroscopic images.

\subsubsection{Collection of Blood and Tissue}

After sacrifice under chloral hydrate anesthesia, blood samples were collected by cardiac puncture and centrifuged at $2700 \times g$ for $15 \mathrm{~min}$ for various biochemical parameters, 
such as fribrinogen markers. The skin samples were collected, and the dissected wound tissue was used for analysis of oxidative damage markers and the enzymatic antioxidant defense system. For oxidative stress profile studies, each collected wound tissue was homogenized in TBS buffer (Tris- $\mathrm{HCl} 50 \mathrm{mM}$ and $\mathrm{NaCl} 150 \mathrm{mM}(1: 2, w / v)$ ) at pH 7.4 using an Ultra-Turax homogenizer. After centrifugation at $10,000 \times g$ for $15 \mathrm{~min}$ at $4^{\circ} \mathrm{C}$, the supernatant was used to determine the protein content, as described by Lowry et al. [52]

\subsubsection{Determination of Inflammatory Markers}

Inflammatory markers of treated and control rats were evaluated after the sacrifice by measuring fibrinogen levels in blood samples. The level of fibrinogen was measured using a commercial kit obtained from STA Liquid fibrinogen (diagnostica stago), according to the manufacturer's instructions.

\subsection{Determination of Oxidative Stress Markers of Granulation Tissue}

\subsubsection{Thiobarbituric Acid Reactive Substances (TBARS)}

TBARS was assessed after the sacrifice using the spectrophotometric method described by Buege and Aust [53]. A total of $375 \mu \mathrm{L}$ of extract, $150 \mu \mathrm{L}$ of TBS and $375 \mu \mathrm{L}$ of TCA $20 \%$ and $1 \%$ BHT were mixed to deproteinize the extracts. After centrifugation $(1000 \times g$ for $10 \mathrm{~min}), 400 \mu \mathrm{L}$ of the supernatant were mixed with $80 \mu \mathrm{L}$ of $\mathrm{HCl}(0.6 \mathrm{M})$ and $320 \mu \mathrm{L}$ of TrisTBA (26 mMTris, $120 \mathrm{mM}$ thiobarbituric acid). The optical density was measured at $530 \mathrm{~nm}$. The TBARS amount was measured using $0.156 \mathrm{mM}^{-1} \mathrm{~cm}^{-1}$ as the extinction coefficient.

\subsubsection{Conjugated Diene (CD)}

Conjugated diene levels were evaluated after the sacrifice by Halliwell and Gutteridge [54]. A total of $25 \mu \mathrm{L}$ of wound tissue, $3 \mathrm{~mL}$ of chloroform and methanol (2:1, $v / v$ ) were mixed and then centrifuged at $3000 \mathrm{rpm}$ for $5 \mathrm{~min}$. An amount of $2 \mathrm{~mL}$ of the supernatant were taken and dried at $45{ }^{\circ} \mathrm{C}$ overnight. The extract obtained is again dissolved in $2 \mathrm{~mL}$ of methanol. We read the OD at $190 \mathrm{~nm}$.

\subsubsection{Advanced Oxidation of Protein Products Levels (AOPP)}

The AOPP level was assessed after the sacrifice using the spectrophotometric method described by Witko et al. [55] Amounts of $200 \mu \mathrm{L}$ of potassium iodide and $20 \mu \mathrm{L}$ of acetic acid were placed in the presence of the sample diluted using $800 \mu \mathrm{L}$ of PBS. AOPP has the capacity to absorb at $340 \mathrm{~nm}$ in an acid medium. Chloramine- $\mathrm{T}(0$ to $200 \mu \mathrm{M})$ used as standard absorbed at $340 \mathrm{~nm}$ in the presence of potassium iodide.

\subsubsection{Carbonyl Protein (CP)}

The CP was assessed after the sacrifice using the spectrophotometric method described by Reznick and Packer [56]. A solution of TCA (20\%) was added to the samples of the homogenate in order to precipitate the proteins. Then, a solution of DNPH (10 mM) was solubilized in $\mathrm{HCl}(2 \mathrm{~N})$ for $1 \mathrm{~h}$ at room temperature. The mixture was centrifuged for $15 \mathrm{~min}$ at $4{ }^{\circ} \mathrm{C}$ at $4000 \times g$. The samples were treated with a guanidine- $\mathrm{HCl}$ solution $(6 \mathrm{M})$ and placed in water at a temperature of $37^{\circ} \mathrm{C}$ for $15 \mathrm{~min}$. The protein carbonyl content was measured at $370 \mathrm{~nm}$ against a guanidine blank using a molar extinction coefficient of $22,000 \mathrm{M} \mathrm{cm}^{-1}$.

\subsection{Determination of Enzymatic Antioxidant Profile of the Granulation Tissue 3.6.1. Superoxide Dismutase Activity (SOD)}

SOD activity was assessed after the sacrifice using the spectrophotometric method described by Beyer and Fridovich [57]. The reaction mixture containing $50 \mathrm{mM}$ of the tissue homogenates was prepared; then, the absorbance was measured at $560 \mathrm{~nm}$ and the SOD activity was expressed as unit per $\mathrm{mg}$ of protein (Unit/mg protein). 


\subsubsection{Glutathione Peroxidase Activity (GPx)}

GPx activity was assessed after the sacrifice using the method described by Flohe and Gunzler [58] using 5\% TCA. After centrifugation at $1500 \times g$ for $10 \mathrm{~min}$, the supernatant was collected. A total of $0.1 \mathrm{~mL}$ of the tissue supernatant was mixed with $0.7 \mathrm{~mL}$ of 5.50 dithiobis-(2-nitrobenzoic acid) and (DTNB, $0.4 \mathrm{mg} / \mathrm{mL}$ ) and $0.2 \mathrm{~mL}$ of phosphate buffer (0.1 M pH 7.4). The absorbance was measured at $420 \mathrm{~nm}$ and the GPx activity was expressed as nmoles of $\mathrm{GSH} / \mathrm{min} / \mathrm{mg}$ protein.

\subsubsection{Catalase Activity (CAT)}

CAT activity was assessed after the sacrifice using the method described by Aebi [59]. Briefly, $20 \mu \mathrm{L}$ of tissue homogenate was added to $880 \mu \mathrm{L}$ of $\mathrm{H}_{2} \mathrm{O}_{2}$ solution $(\mathrm{pH}=7.4)$, which contains $0.5 \mathrm{~mol} / \mathrm{L} \mathrm{H}_{2} \mathrm{O}_{2}$ and $0.1 \mathrm{~mol} / \mathrm{L}$ of phosphate buffer. The principle of the method is based on monitoring the $\mathrm{H}_{2} \mathrm{O}_{2}$ decomposition spectrophotometrically at $290 \mathrm{~nm}$ via the absorbance decrease. The extinction coefficient was $0.043 / \mathrm{mM}^{-1} \mathrm{~cm}^{-1}$ and the enzyme activity was expressed as $\mu \mathrm{mol}_{2} \mathrm{O}_{2}$ decomposed $/ \mathrm{min} / \mathrm{mg}$ of protein $(\mu \mathrm{M} / \mathrm{min} / \mathrm{mg}$ protein).

\subsection{Statistical Analysis}

All results were expressed as mean \pm standard error of the mean (SEM). Differences were considered statistically significant at $p \leq 0.05$. The results were analyzed by one-way analysis of variance (ANOVA) to assess the comparisons between groups using SPSS for Windows (version 18).

\section{Conclusions}

In conclusion both ASE and ASO possessed interesting amounts of polyphenols. Nevertheless, ASO was shown to contain more flavonoids and polyphenols. These high levels were associated with good antioxidant potential as assessed by DPPH, FRAP, ABTS and total antioxidant capacity and experimental wound healing in rats. They were also associated with better activity in terms of inflammation biomarkers, antioxidant parameters and wound healing activity. The latter revealed significantly accelerated both reepithelialization and vascularization processes. The polyphenol, flavonoid and tannin contents of AS paralleled the positive effects on wound healing and the inflammatory reduction in the wound-healing treated rats. These results confirmed the ethno-pharmacological potential of Allium subhirsutum and encourage its use in the pharmaceutical industry due to its promising activity, particularly the oil fraction.

Supplementary Materials: The following are available online. Figure S1. Calibration curves of total phenolic components, flavonoids and tannins. OD: Optical density.

Author Contributions: Conceptualization, M.S. (Mongi Saoudi) and R.B.; methodology, M.S. (Mongi Saoudi) and A.C.; software, M.S. (Mongi Saoudi); validation, R.B., M.S. (Mohd Saeed) and A.E.F.; investigation, M.S. (Mongi Saoudi); R.B; resources, C.K. and A.E.F.; data curation, J.M.A.; writingoriginal draft preparation, M.S. (Mongi Saoudi); writing-review and editing, M.S. (Mongi Saoudi) and R.B.; visualization, S.E. and N.B.; supervision, R.B. and A.E.F.; project administration, R.B.; funding acquisition, R.B. All authors have read and agreed to the published version of the manuscript.

Funding: This research was supported by grants from the Deanship of Scientific Research-University of Ha'il (UoH) under a project number RG-20 070.

Institutional Review Board Statement: All animal experiments were conducted according to the Ethical Committee Guidelines for the care and use of laboratory animals of our institution (university of Sfax, Tunisia).

Informed Consent Statement: Not applicable.

Data Availability Statement: All data generated or analyzed during this study are included in this article. 
Conflicts of Interest: The authors declare no conflict of interest.

Sample Availability: Samples of the compounds are available from the authors.

\section{References}

1. Pastar, I.; Wong, L.L.; Egger, A.N.; Tomic-Canic, M. Descriptive vs mechanistic scientific approach to study wound healing and its inhibition: Is there a value of translational research involving human subjects? Exp. Dermatol. 2018, 27, 551-562. [CrossRef]

2. Shetty, S.; Udupa, S.; Udupa, L. Evaluation of antioxidant and wound healing effects of alcoholic and aqueous extract of Ocimum sanctum Linn in rats. Evid. Based Compl. Alt. Med. 2008, 5, 95-101. [CrossRef]

3. Oryan, A.; Alemzadeh, E.; Moshiri, A. Biological properties and therapeutic activities of honey in wound healing: A narrative review and meta-analysis. J. Tissue Viability 2016, 25, 98-118. [CrossRef] [PubMed]

4. Djemaa, F.G.B.; Bellassoued, K.; Zouari, S.; El Feki, A.; Ammar, E. Antioxidant and wound healing activity of Lavandula aspic L. ointment. J. Tissue Viability 2016, 25, 193-200. [CrossRef] [PubMed]

5. Zhou, L.; Xu, T.; Yan, J.; Li, X.; Xie, Y.; Chen, H. Fabrication and characterization of matrine-loaded konjacglucomannan/fish gelatin composite hydrogel as antimicrobial wound dressing. Food Hydrocoll. 2020, 104, 105-702. [CrossRef]

6. Yadav, A.; Verma, S.; Keshri, G.K.; Gupta, A. Role of $904 \mathrm{~nm}$ superpulsed laser-mediated photobiomodulation on nitroxidative stress and redox homeostasis in burn wound healing. Photodermatol. Photoimmunol. Photomed. 2020, 36, 208-218. [CrossRef]

7. Firat, E.T.; Dağ, A.; Günay, A.; Kaya, B.; Karadede, M.İ.; Kanay, B.E.; Ketani, A.; Evliyaoglu, O.; Uysal, E. The effects of low-level laser therapy on palatal mucoperiosteal wound healing and oxidative stress status in experimental diabetic rats. Photomed. Laser Surg. 2013, 31, 315-321. [CrossRef] [PubMed]

8. Serarslan, G.; Altuğ, E.; Kontas, T.; Atik, E.; Avci, G. Caffeic acid phenetyl ester accelerates cutaneous wound healing in a rat model and decreases oxidative stress. Clin. Exp. Dermatol. 2007, 32, 709-715. [CrossRef] [PubMed]

9. Badraoui, R.; Sahnoun, Z.; Abdelmoula, N.B.; Hakim, A.; Fki, M.; Rebaï, T. May antioxidant status depletion by Tetradifon induce secondary genotoxicity in female Wistar rats via oxidative stress? Pestic. Biochem. Physiol. 2007, 88, 149-155. [CrossRef]

10. Badraoui, R.; Alrashedi, M.M.; El-May, M.V.; Bardakci, F. Acute respiratory distress syndrome: A life threatening associated complication of SARS-CoV-2 infection induced COVID-19. J. Biomol. Struct. Dyn. 2020, 1-10. [CrossRef] [PubMed]

11. Zammel, N.; Saeed, M.; Bouali, N.; Elkahoui, S.; Alam, J.M.; Rebai, T.; Kausar, M.A.; Adnan, M.; Siddiqui, A.J.; Badraoui, R. Antioxidant and anti-inflammatory effects of Zingiberofficinaleroscoe and Allium subhirsutum: In Silico, biochemical and histological study. Foods 2021, 10, 1383. [CrossRef]

12. Bai, Q.; Han, K.; Dong, K.; Zheng, C.; Zhang, Y.; Long, Q.; Lu, T. Potential Applications of Nanomaterials and Technology for Diabetic Wound Healing. Int. J. Nanomed. 2020, 15, 9717. [CrossRef]

13. Akacha, A.; Badraoui, R.; Rebai, T.; Zourgui, L. Effect of Opuntiaficusindica extract on methotrexate-induced testicular injury: A biochemical, docking and histological study. J. Biomol. Struct. Dyn. 2020, 1-11. [CrossRef]

14. Mzid, M.; Badraoui, R.; Khedir, S.B.; Sahnoun, Z.; Rebai, T. Protective effect of ethanolic extract of Urticaurens L. against the toxicity of imidacloprid on bone remodeling in rats and antioxidant activities. Biomed. Pharmacother. 2017, 91, 1022-1041. [CrossRef] [PubMed]

15. Sharif, A.; Asif, H.; Younis, W.; Riaz, H.; Bukhari, I.A.; Assiri, A.M. Indigenous medicinal plants of Pakistan used to treat skin diseases: A review. Chin. Med. 2018, 13,1-26.

16. Rekik, D.M.; Khedir, S.B.; Daoud, A.; Moalla, K.K.; Rebai, T.; Sahnoun, Z. Wound Healing Effect of Lawsoniainermis. Skin Pharmacol. Physiol. 2019, 32, 295-306. [CrossRef]

17. Badraoui, R.; Rebai, T.; Elkahoui, S.; Alreshidi, M.; Veettil, V.N.; Noumi, E.; Al-Motair, A.K.; Aouadi, K.; Kadri, A.; De Feo, V.; et al. Allium subhirsutum L. as a Potential Source of Antioxidant and Anticancer Bioactive Molecules: HR-LCMS Phytochemical Profiling, In Vitro and In Vivo Pharmacological Study. Antioxidants 2020, 9, 1003. [CrossRef]

18. Saoudi, M.; Badraoui, R.; Rahmouni, F.; Jamoussi, K.; El Feki, A. Antioxidant and protective effects of Artemisia campestris essential oil against chlorpyrifos-induced kidney and liver injuries in rats. Front. Physiol. 2021, 12, 194. [CrossRef] [PubMed]

19. Rahmouni, F.; Saoudi, M.; Amri, N.; El-Feki, A.; Rebai, T.; Badraoui, R. Protective effect of Teucriumpolium on carbon tetrachloride induced genotoxicity and oxidative stress in rats. Arch. Physiol. Biochem. 2018, 124, 1-9. [CrossRef] [PubMed]

20. Edwards, Q.T.; Colquist, S.; Maradiegue, A. What's cooking with garlic: Is this complementary and alternative medicine for hypertension? J. Am. Assoc. Nurse Pract. 2005, 17, 381-385. [CrossRef] [PubMed]

21. Sut, S.; Maggi, F.; Bruno, S.; Badalamenti, N.; Quassinti, L.; Bramucci, M.; Beghelli, D.; Lupidi, G.; Dall'Acqua, S. Hairy garlic (Allium subhirsutum) from Sicily (Italy): LC-DAD-MSn analysis of secondary metabolites and in vitro biological properties. Molecules 2020, 25, 2837. [CrossRef]

22. Sener, G.; Sakarcan, A.; Yeğen, B.Ç. Role of garlic in the prevention of ischemia-reperfusion injury. Mol. Nutr. Food Res. 2007, 51, 1345-1352. [CrossRef]

23. Kothari, D.; Lee, W.D.; Kim, S.K. Allium Flavonols: Health Benefits, Molecular Targets, and Bioavailability. Antioxidants 2020, 9, 888. [CrossRef]

24. Khan, M.S.; Qureshi, N.A.; Jabeen, F.; Wajid, M.; Sabri, S.; Shakir, M. The role of garlic oil in the amelioration of oxidative stress and tissue damage in rohuLabeorohita treated with silver nanoparticles. Fish. Sci. 2020, 86, 255-269. [CrossRef]

25. Juan-García, A.; Agahi, F.; Drakonaki, M.; Tedeschi, P.; Font, G.; Juan, C. Cytoprotection assessment against mycotoxins on HepG2 cells by extracts from Allium sativum L. Food Chem. Toxicol. 2021, 151, 112-129. [CrossRef] [PubMed] 
26. Batiha, G.E.S.; Alkazmi, L.M.; Wasef, L.G.; Beshbishy, A.M.; Nadwa, E.H.; Rashwan, E.K. Syzygiumaromaticum L. (Myrtaceae): Traditional uses, bioactive chemical constituents, pharmacological and toxicological activities. Biomolecules 2020, 10, 202. [CrossRef] [PubMed]

27. Polerà, N.; Badolato, M.; Perri, F.; Carullo, G.; Aiello, F. Quercetin and its natural sources in wound healing management. Curr. Med. Chem. 2019, 26, 5825-5848. [CrossRef]

28. Hemmatpor, Z.; Kamali, J.; Mehrabani, M.; Hashemi, S.A.; Marashi, S.M.A.; Pahlevan, S.; Tavakoli-Far, B. Study the Effect of Aqueous Extract of Garlic (Allium sativum) on Healing Procedure of Burn Wound on Rat. Egypt. J. Vet. Sci. 2020, 51, 181-189. [CrossRef]

29. Nagori, B.P.; Solanki, R. Role of medicinal plants in wound healing. Res. J. Med. Plants 2011, 5, 392-405. [CrossRef]

30. Majumdar, A.; Sangole, P. Alternative approaches to wound healing. Alexandrescu VA. In Wound Healing: New insights into Ancient Challenges; IntechOpen: London, UK, 2016; p. 459.

31. Amagase, H.; Petesch, B.L.; Matsuura, H.; Kasuga, S.; Itakura, Y. Intake of garlic and its bioactive components. J. Nutr. 2001, 131, 955S-962S. [CrossRef]

32. Farhat, Z.; Hershberger, P.A.; Freudenheim, J.L.; Mammen, M.J.; Blair, R.H.; Aga, D.S.; Mu, L. Types of garlic and their anticancer and antioxidant activity: A review of the epidemiologic and experimental evidence. Eur. J. Nutr. 2021, 1-25. [CrossRef]

33. Jantan, I.; Haque, M.A.; Arshad, L.; Harikrishnan, H.; Septama, A.W.; Mohamed-Hussein, Z.A. Dietary polyphenols suppress chronic inflammation by modulation of multiple inflammation-associated cell signaling pathways. J. Nutr. Biochem. 2021, 93, 108634. [CrossRef]

34. Yadav, E.; Singh, D.; Yadav, P.; Verma, A. Attenuation of dermal wounds via downregulating oxidative stress and inflammatory markers by protocatechuic acid rich n-butanol fraction of Trianthemaportulacastrum Linn. in wistar albino rats. Biomed. Pharmacother. 2017, 96, 86-97. [CrossRef] [PubMed]

35. Badraoui, R.; Nasr, H.B.; Louati, R.; Ellouze, F.; Rebai, T. Nephrotoxic effect of tetradifon in rats: A biochemical and histomorphometric study. Exp. Toxicol. Pathol. 2012, 64, 645-650. [CrossRef]

36. Amri, N.; Rahmouni, F.; Chokri, M.A.; Rebai, T.; Badraoui, R. Histological and biochemical biomarkers analysis reveal strong toxicological impacts of pollution in hybrid sparrow (Passer domesticus $\times$ Passerhispaniolensis) in southern Tunisia. Environ. Sci. Pollut. Res. 2017, 24, 17845-17852. [CrossRef] [PubMed]

37. Ben Nasr, H.; Hammami, S.; Chaker, S.; Badraoui, R.; Sahnoun, Z.; Jamoussi, K.; Rebai, T.; Zeghal, K. Some biological effects of scorpion envenomation in late pregnant rats. Exp. Toxicol. Pathol. 2009, 61, 573-580. [CrossRef]

38. Cano Sanchez, M.; Lancel, S.; Boulanger, E.; Neviere, R. Targeting oxidative stress and mitochondrial dysfunction in the treatment of impaired wound healing: A systematic review. Antioxidants 2018, 7, 98. [CrossRef] [PubMed]

39. Yadav, E.; Singh, D.; Yadav, P.; Verma, A. Antioxidant and anti-inflammatory properties of Prosopis cineraria based phenolic rich ointment in wound healing. Biomed. Pharmacother. 2018, 108, 1572-1583. [CrossRef] [PubMed]

40. Ansary, J.; Forbes-Hernández, T.Y.; Gil, E.; Cianciosi, D.; Zhang, J.; Elexpuru-Zabaleta, M.; Simal-Gandara, J.; Giampieri, F.; Battino, M. Potential health benefit of garlic based on human intervention studies: A brief overview. Antioxidants 2020, 9, 619. [CrossRef]

41. Li, B.; Cheng, Z.; Sun, X.; Si, X.; Gong, E.; Wang, Y.; Tian, J.; Shu, C.; Ma, F.; Li, D.; et al. Lonicera caerulea L. polyphenols alleviate oxidative stress-induced intestinal environment imbalance and lipopolysaccharide-induced liver injury in HFD-fed rats by regulating the Nrf2/HO-1/NQO1 and MAPK pathways. Mol. Nutr. Food Res. 2020, 64, 1901315. [CrossRef]

42. Arişanu, A.O.; Rus, F. Current techniques and processes for vegetable oil extraction from oilseed crops. Bull. Transilv. Univ. Bras. 2017, 10, 65-70.

43. Wolfe, K.; Wu, X.; Liu, R.H. Antioxidant activity of apple peals. J. Agric. Food Chem. 2003, 51, 609-614. [CrossRef] [PubMed]

44. Chang, C.C.; Yang, M.H.; Wen, H.M.; Chern, J.C. Estimation of total flavonoid content in propolis by two complementary colorimetric methods. J. Food Drug Anal. 2002, 10, 178-182.

45. Broadhurst, R.B.; Jones, W.T. Analysis of condensed tannins using acidified vanillin. J. Sci. Food Agric. 1978, $29,788-794$. [CrossRef]

46. Kirby, A.J.; Schmidt, R.J. The antioxidant activity of Chinese herbs for eczema and of placebo herbs. J. Ethnopharmacol. 1997, 56, 103-108. [CrossRef]

47. Oyaizu, M. Studies on products of browning reactions: Antioxidative activities of browning reaction prepared from glucosamine. Jpn. J. Nutr. 1986, 44, 307-315. [CrossRef]

48. Re, R.; Pellegrini, N.; Proteggente, A.; Pannala, A.; Yang, M.; Rice-Evans, C. Antioxidant activity applying an improved ABTS radical cation decolorization assay. Free Radic. Biol. Med. 1999, 26, 1231-1237. [CrossRef]

49. Prieto, P.; Pineda, M.; Aguilar, M. Spectrophotometric quantitation of antioxidant capacity through the formation of a phosphomolybdenum complex: Specific application to the determination of vitamin E. Anal. Biochem. 1999, 269, 337-341. [CrossRef]

50. Suguna, L.; Singh, S.; Sivakumar, P.; Sampath, P.; Chandrakasan, G. Influence of Terminalia chebula on dermal wound healing in rats. Phytother. Res. 2002, 16, 227-231. [CrossRef]

51. Jridi, M.; Sellimi, S.; Lassoued, K.B.; Beltaief, S.; Souissi, N.; Mora, L.; Toldra, F.; Elfeki, A.; Nasri, M.; Nasri, R. Wound healing activity of cuttlefish gelatin gels and films enriched by henna (Lawsoniainermis) extract. Colloid Surf. A Physicochem. Eng. Asp. 2017, 512, 71-79. [CrossRef] 
52. Lowry, O.H.; Rosebrough, N.J.; Farr, A.L.; Randall, R.J. Protein measurement with Folin phenol reagent. J. Biol. Chem. 1951, 193, 265-275. [CrossRef]

53. Buege, J.A.; Aust, S.D. Microsomal lipid peroxidation. Methods Enzymol. 1972, 51, 302-310.

54. Halliwell, B.; Gutteridge, J.C. Lipid peroxidation, oxygen radicals, cell damage, and antioxidant therapy. Lancet (Br. Ed.) 1984, 8391, 1396-1397. [CrossRef]

55. Witko-Sarsat, V.; Friedlander, M.; Capeillère-Blandin, C.; Nguyen- Khoa, T.; Nguyen, A.T.; Zingraff, J.; Jungers, P.; DescampsLatscha, B. Advanced oxidation protein products as a novel marker of oxidative stress in uremia. Kidney Int. 1996, 49, 1304-1313. [CrossRef]

56. Reznick, A.Z.; Packer, L. Oxidative damage to proteins: Spectrophotometric method for carbonyl assay. Methods Enzymol. 1994, 233, 357-363. [PubMed]

57. Beyer, W.F.; Fridovich, I. Assaying for superoxide dismutase activity: Some large consequences of minor changes in conditions. Anal. Biochem. 1987, 161, 559-566. [CrossRef]

58. Floche, L.; Gunzler, W.A. Analysis of glutathione peroxidase. Methods Enzymol. 1984, 105, 114-121.

59. Aebi, H. Catalase in vitro. Methods Enzymol. 1974, 105, 121-126. 